\title{
Analysis Effect of Sedimentation at MHP Type Turbine Open Flume on Irrigation Channel
}

\author{
Arifin Matoka ${ }^{1}$, Nadjamuddin H. ${ }^{2}$, Salama M. ${ }^{3}$ and M. Arsyad T. \\ ${ }^{1}$ (Student of Doctoral Program in Civil Engineering, Hasanuddin University, Macassar-Indonesia,) \\ ${ }^{2}$ (Lecturer of Department of Electrical Engineering, Hasanuddin University, Macassar-Indonesia.) \\ ${ }^{3}$ (Lecturer of Department of Electrical Engineering, Hasanuddin University, Macassar-Indonesia.) \\ ${ }^{4}$ (Lecturer of Department of Civil Engineering, Hasanuddin University, Macassar-Indonesia.)
}

\begin{abstract}
The MHP utilization in irrigation canals wear Plopeler Open Flume turbine type. PLTMH of this type, in the rainy seas on affects the quality of the electrical power produced, such as the generator voltage $\mathrm{V}$ (Volt), turbine / gen $\mathrm{n}(\mathrm{rpm})$, and frequency $(\mathrm{Hz})$. This research method is done with 5 -step procedure of four variables measured data from three case scenarios ie when there is no rain, the rain and after rain. The result analysis was conducted on all statistical calculations visible negative correlation means that if kosenrtasi sedimentation $\mathrm{C}$ increases, the voltage generator, turbine-generator rotation $\mathrm{n}(\mathrm{rpm})$, and the frequency $\mathrm{f}(\mathrm{Hz})$ of The MHP is going down. From test the hypothesis stated that there is a significant relationship with the $t$-test of 16.92 , then $\mathrm{t}$ count $>\mathrm{t}$ table at $\alpha=5 \%$. namely 2101 . By the time the rain to kosenrtasi sed imentation C (g/ lt) $\mathrm{C}=1.00$ to $2.50 \mathrm{~g} / 1$ (medium), 2.50 to $5.00 \mathrm{~g} / 1 \mathrm{ugly}$ with voltage deviation $\mathrm{Vd}=17.6 \%$, deviation $\mathrm{Fd}$ frequency deviation $=6.8 \%$ and $6.8 \%$ round $\mathrm{Nd}=$ The MHP abnormal conditions. Given this research can be a reference for the exploitation of MHP by communities around the irigas channel as a reference basis for the development of the National Irrigation Project.
\end{abstract}

Keywords: MHP, open flu me propeller turbine, irrigation, sedimentation.

\section{INTRODUCTION}

\subsection{Background}

PLMTH the irrigation channel has a high fall (head) effective relatively low (under 5 meters), where the turbine is used turbine types Plopeler Open Flume that includes type turbine reaction which is a water turbine with the way it works to change the entire energy of water available into torsional energy. From field observations MHP on irrigation channels, it appears that in the event of water turbidity caused by season penghujanan which resulted in the lifting of soil sediments greatly affect the quality of the electrical power produced, such as a variable voltage generator $\mathrm{V}$ (Volt), turbine / generator $\mathrm{n}(\mathrm{rpm})$ and frequency $\mathrm{f}$ (Hz)

\subsection{Problem Formulation}

From the above it can be formulated permasaalahan exposure of this study are as follows:

1. Is there any influence sedimentation irrigation canals with sedimentation kosenrtasi parameters, in various conditions circumstances against voltage parameter generator, turbine / generator, frequency generator in micro hydro power plant that uses a type turnin Open Flu me propeller.

2. How big is the influence formulate relationships during rainy conditions of variable turbine / gen, generator voltage, frequency on Micro-Hydro Power Plant on the type of propeller Open turnin Flume.

3. What recommendations can be obtained from the amount of sediment concentration on the type of turbine Plopeler Open Flume used in MHP utilized in irrigation channels were conducted in this study.

\subsection{Objecti ves Research}

From the formulation of the above problems, the purpose of this study are:

1. Obtain the magnitude correlation kosenrtasi sedimentation $\mathrm{C}(\mathrm{g} / \mathrm{lt})$, with the generator voltage (volts), the turbine-generator rotation $n$ $(\mathrm{rpm})$, and the frequency $\mathrm{f}(\mathrm{Hz})$ which may 
affect the MHP, in rainy conditions, completed the rain and no rain.

2. Conduct a test analyst in rainy conditions on the effects of sedimentation kosenrtasi C ( $\mathrm{g} /$ lt), see what percentage deviation of the voltage $\mathrm{V}$ (Volt), deviation of the turbinegenerator rotation $\mathrm{n}(\mathrm{rpm})$ and the deviation of the frequency $\mathrm{f}(\mathrm{Hz})$ of the limit of allowable deviation stadar,

3. Getting a recommendation from the amount of sediment concentration on the type of turbine Plopeler Open Flume used in MHP utilized in irrigation channels were conducted in this study.

\subsection{Benefits Research}

The benefits of this research are:

1. Can be used as a scientific reference for the utilization of irrigation channels to mikrohydro type turbine generator Plopeler Open Flume nationally

2. Being a program supporting the maintenance and rehabilitation of irrigation canals from the relevant authorities after the irrigation project was completed and handed over to the area.

3. Provide a contribution utilization of electrical energy for electrical machinery in agriculture and also empower the community on environmental aspects, support the government's program on renewable energy utilization.

\section{BASIC THEORY}

\subsection{Power Genereted}

The power that can be produced into electrical energy where power is generated in turn were able to move the processing tool farmland, agricultural products processing tool for facilities or other electrical appliances for household use during the day, and for lighting at night, Power generated by a MHP is :

$P=k \cdot h \cdot Q \cdot \eta_{t} \cdot \eta_{g}[k W]$

Where; $\mathrm{P}=$ power $[\mathrm{kW}], \mathrm{h}=$ high effective fall $(\mathrm{m})$ maximum [meter], $\mathrm{Q}=$ discharge $(\mathrm{m} 3 / \mathrm{s}), \mathrm{t} \eta=$ turbine efficiency, $\mathrm{g} \eta=$ efficiency of the generator, $\mathrm{k}=$ constant (9.8)

\subsection{Type Turbine on MHP Irrigation}

MHP in the irrigation channel has a high fall (head) effective relatively low (under 5 meters), where the turbine is used turbine types Plopeler Open Flume is included type reaction turbine which is a water turbine with the way it works to change the entire energy of water available into torsional energy. as show the Fig. 1.

\subsection{Generator on the MHP}

Direct current flow in the rotor coil is rotated by a turbine, it will be product the electromagnetic force generating in the stator coil. As a result of the magnetic field will cause a rotating magnetic field surrounding the stator coil changes continuously..
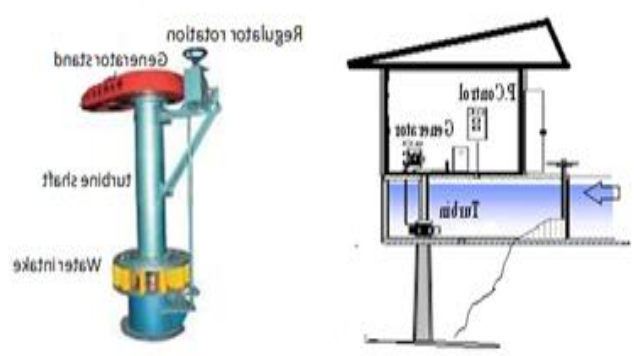

Fig. 1 Open flu me propeller turb ine type

The induced voltage will be sinusoidal and extent of which depends on the strength of the magnetic field and the rotation speed of the rotor. For three-phase generator, the stator coils placed three separate as far as $120^{\circ}$ from each other, In general, also on Power Mikrohydro (MHP) for small-scale uses 1-phase synchronous generator its output voltage as shown in Figure 2 with the illustrations as follows:
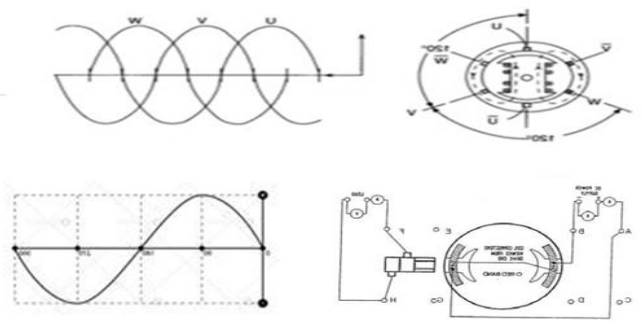

Fig. 2. Output voltage 3-phase and one phase synchronous generator 
In the design 1-phase synchronous generator, sometimes there is a phenomenon in which waves generated not a pure sinusoida, because distortion occurs in the output waveform so-called harmonics. water turbine rotating synchronous generator reaches the actual speed by the prime mover, the field coil is excited by dc currents which cut the field flux conductor induce emf voltage $(\mathrm{Ea})$. Then out in the stator winding terminal which amount is given by the equation:

$$
E_{a}=c n \Phi_{a}
$$

Where ; $\mathrm{c}=$ constant engine, $\mathrm{n}=$ synchronous rotation, $\Phi_{a}=$ flux generated by field current induced voltage $\mathrm{Ea}$ generated in the phase synchronous generators are not equal to the voltage at the terminals of the generator, it is due to their resistance and reactance sync anchor.Equation voltage on the generator is

$E a=V+I \cdot R a+j I X s$

In the power supply system, generally the power supply voltage deviation voltage (Vd) is permitted varies $(+5 \%)$ and $(-10 \%)$ according to the standard of PLN (Indonesian electricity company),

. The frequency is characteristic of the sinusoidal wave voltages and currents generated by the generator. Generator rotation speed is equal to a turbine wheel where the frequency is obtained:

$$
\mathrm{f}=\frac{\mathrm{Pn}}{60}
$$

Where; $\mathrm{f}=$ frequency, $\mathrm{n}=$ speed $(\mathrm{rpm}), \mathrm{p}=$ number of pole pairs generator. $50 \mathrm{hz}$ frequency used, and for the allowable frequency deviation can change the magnitude of $\pm 2 \%$.

\subsection{Sedimentation}

Factors reciprocity between the properties of water flow and sediment properties were affected by the rains cause the lifting of sediment to gravitate. Sedimentation contained in irrigation channels may also affect the specific energy due to irrigation canal irrigation canals dimensional change. Concentration of sediment can be obtain from ratio of dry sediment weight and the total volume of the water sample is given by:

$C=\frac{B K(m g)}{V(l t)}$
Where; BK dry sediment weight (mg), V = Volu me of sample water (liter).

Sedimentation rate can be obtained from multiplying the water discharge and sediment concentration by the equation:

$Q_{S}=0,0864 C Q$

\subsection{Effect of the sediment concentration, voltage frequency and rotation.}

The influence of sediment concentration

(C) of the MHP Open Flu me Propeller turbine type of parameter voltage (V), rotation (n) and frequency $(\mathrm{Hz})$ of this research is to use the statistic test because by theoretically not yet developed.As for the statistical testing is as follows:

a. Make sediment concentration data summary table (as a function of the variable $\mathrm{x}$ ), while voltage generator (v), rotating turbin-generator (n), frequency $(\mathrm{Hz})$, (as variables $\mathrm{y}_{1}, \mathrm{y}_{2}, \mathrm{y}_{3}$ ).

b. Determining the regression model with the following formula:

$$
\begin{aligned}
& y=b_{O}+b_{1} x . \\
& b_{1}=\frac{n \sum_{i=1}^{n} X_{i} Y_{i}-\sum_{i=1}^{n} X_{i} \sum_{i=1}^{n} Y_{i}}{n \sum_{i=1}^{n} X_{i}^{2}-\left(\sum_{i=1}^{n} X_{i}\right)}
\end{aligned}
$$

$$
b_{o}=\bar{y}-b_{i} \bar{x}
$$

c. Looking Correlation Coefficient

$\rho=\frac{\operatorname{Cov}(x, y)}{S_{x} S_{y}}$

a. covariance can be searched using the formula:

$\operatorname{Cov}(x, y)=\frac{\sum\left(x_{i}-\bar{x}\right)\left(y_{i}-\bar{y}\right)}{n-1}$

Then the correlation coefficient obtained:

$r_{x y}=\frac{N \sum X Y-\left(\sum X\right)\left(\sum Y\right)}{\sqrt{\left(N \sum X^{2}-\left(\sum X\right)^{2}\right)\left(N \sum Y^{2}-\left(\sum Y\right)^{2}\right)}}$

Next to test the hypothesis of correlation

Ho: There is no significant relationship between concentration sedimentation c (mg / lt) by, Voltage, Frequency and rotating turbine / gen $\mathrm{n}$ (rpm)

H1: There is a significant relationship between cosenrtation sedimentation c (mg / lt) with Round turbine / generator ( $\mathrm{rpm}$ )

To test the hypothesis in correlation with the search for the value of the correlation coefficient $t$ statistic is then compared with t-table

$t_{o}=\left|\frac{r \sqrt{n-2}}{\sqrt{1-r^{2}}}\right|$

d. coefficient of Determination 
To consider the regression model accuracy can be checked by calculating the coefficient of determination:

$r_{x y}=\frac{n \sum_{i=1}^{n} X_{i} Y_{i}-\sum_{i=1}^{n} X_{i} \sum_{i=1}^{n} Y_{i}}{\sqrt{n \sum_{i=1}^{n} X_{i}^{2}-\left(\sum_{i=1}^{n} X_{i}\right)^{2}} \sqrt{n \sum_{i=1}^{n} Y_{i}^{2}-\left(\sum_{i=1}^{n} Y_{i}\right)^{2}}}$

$R^{2}=\frac{S S_{R}}{S E_{\mathrm{XY}}}=\frac{\sum_{j=1} n\left(\bar{y}_{i}-\bar{y}\right)^{2}}{\sum_{j=1} n\left(y_{i}-\bar{y}\right)^{2}}$

$\mathrm{R} 2$ value is $0 \leq \mathrm{R} 2 \leq 1$ which is the amount of variability in the data obtained in the model regreasi.

\section{RESEARCH METHODS}

As this study can be carried out following the draft as follows:

1. Sampling sediment taken with a sampling drift. Type USDH 48 to get water containing sediment drift.

a. Measurements of water containing sediment floating on sediment concentrations to get kosenrtasi sedimentation $\mathrm{C}$ (g/lt).

b. Measurement output generator to get Gener ator voltage variable V (Volt)

c. Measurement output turbine / generator to get the variable turbine / generator $\mathrm{n}(\mathrm{rpm})$.

d. Measurement output generator to get a variable frequency $(\mathrm{Hz})$.

2. sampling and measurement in the rain (high sediment concentrations) procedures a through $\mathrm{c}$ are recorded in Table 1

3. The sampling and measurement upon completion rain (concentration of sediment being) the procedures a through $\mathrm{c}$ are recorded in Table 1.

4. The sampling and measurement at the time there was no rain (small sediment concentration)) with a procedure to $\mathrm{c}$ noted in Table 1.

5. The sampling and measurement in the rain as much as 20 samples with a procedure to $\mathrm{c}$. noted in Table 2 Correlations between variables were observed in the MHP system based on test statistics. The flow chart as shown in the figure

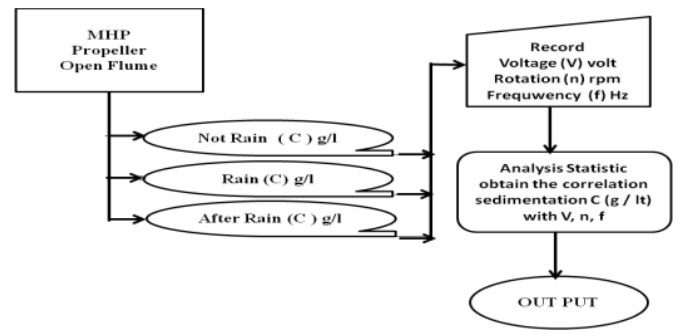

Fig. 3. Flowchart research

\section{DISCUSSION AND ANALYSIS}

4.1. Overview of Research Object of MHP Tulabolo.

Based of field conditions in this study with the parameter on measurements were obtained: $\mathrm{A}=$ $2.48 \mathrm{~m}^{2}, \mathrm{~V}=0789 \mathrm{~m} / \mathrm{s}$, it is obtained: $\mathrm{Q}=2.48 \mathrm{~m}^{2}$ x $0789 \mathrm{~m} / \mathrm{s}=1.96 \mathrm{~m}^{3} / \mathrm{s}$, with $\mathrm{k}=9.8$ and higher draft tube $\mathrm{h}=1.75 \mathrm{~m}$, from equation $1.2,3$. theoretical power $\mathrm{P}=\mathrm{k} . \mathrm{h} . \mathrm{Q}=33.614[\mathrm{KW}]$

This power is divided into 6 generating units so that each plant produces theoretically power of 5.6 $\mathrm{KW}$, the efficiency of each ie:. $\eta$ draftube $0.95, \eta$ turbine $0.7, \eta$ generator 0,95 , turbine power is $\mathrm{P}$ $=3.92[\mathrm{~kW}]$ So that the power generator the calculation results $\mathrm{P}=3.5[\mathrm{~kW}]$ per unit.

Generator MHP on the research capacity of $3 \mathrm{KW}$ per unit. with existing data as follows:

Type $\quad: \mathrm{ST}-10 \operatorname{Cos} \varphi \quad: 1.0$

Power :3 KW Exitasi Volt : 80 Volt

Voltage :220 Volt Exitasicurrent : 2 ampere

Current :13,6 A Frekuency : $50 \mathrm{~Hz}$

Rotation :1500 rpm Standar : Q/MD1001- 1998

The influence of sediment concentration (C) of the voltage (volts) on the MHP of the test statistic. the table I can be explained through correlation and regression equations.

\subsection{Determining the model}

To determine the equation of model linear regression using equations 11,12 and 13 as follows

$$
\begin{aligned}
y & =b_{O}+b_{1} x . \text { Where } \\
b_{1} & =\frac{20(7954.76)-(42.762 \times 3873.45)}{20(115.303)-(42.762)} \\
b_{1} & =\frac{-6541.2689}{2263.298}=-2.89 \\
b_{o} & =\bar{Y}-b_{i} \bar{X}=199.85
\end{aligned}
$$

Then the linear regression equation model the influence of sediment concentration on voltage generator is:

$$
Y=-2.89+199.85 X
$$


Tabel I. Data of sedimentation Concentration againts voltage, rotationand frequency generator that circumstances rains and after rains and not rains.

\begin{tabular}{|c|c|c|c|c|c|}
\hline No & $\begin{array}{l}\text { Concentration } \\
\text { se dimentation } \\
c(g / l t), X\end{array}$ & $\begin{array}{l}\text { Voltage } \\
\text { Cen V } \\
\text { (Volt) } Y_{1}\end{array}$ & $\begin{array}{c}\text { Rotation } \\
\text { tur/gen } \\
\text { n(rpm), } Y_{2}\end{array}$ & $\begin{array}{l}\text { Frekuency } \\
\qquad(\mathrm{Hz}) \mathrm{Y}_{3}\end{array}$ & $\begin{array}{l}\text { Information } \\
\text { Condition }\end{array}$ \\
\hline 1 & 2.551 & 182.94 & 1412.98 & 47.11 & Rains $(12,01 / 2015)$ \\
\hline 2 & 2.329 & 189.68 & 1427.68 & 47.57 & After raining (12/01/2015). \\
\hline 3 & 0.451 & 219.87 & 1500.00 & 50.00 & No Rains ( 21,01/2015). \\
\hline 4 & 2.756 & 182.14 & 1412.26 & 47.05 & Rains $(13,02 / 2015)$ \\
\hline 5 & 2.363 & 188.86 & 1426.96 & 47.48 & After raining $(13,02 / 2015)$. \\
\hline 6 & 0.487 & 218.57 & 1496.85 & 49.87 & No Rains $(22,0222015)$ \\
\hline 7 & 2.875 & 181.44 & 1411.42 & 46.97 & Rains $(14,03 / 2015)$ \\
\hline 8 & 2.397 & 188.25 & 1426.31 & 47.42 & After raining (14,03/2015). \\
\hline 9 & 0.55 & 216.65 & 1494.68 & 49.79 & No Rains (23/03/2015). \\
\hline 10 & 2.987 & 180.78 & 1410.73 & 46.91 & Rains $(15,09 / 2015)$ \\
\hline 11 & 2.429 & 187.43 & 1425.43 & 47.34 & After raining ( $15,09 / 2015)$. \\
\hline 12 & 0.598 & 215.45 & 1490.45 & 49.72 & No Rains $(24 / 09 / 2015)$. \\
\hline 13 & 3.467 & 179.86 & 1409.86 & 46.85 & Rains $(16 / 10 / 2015)$ \\
\hline 14 & 2.454 & 186.84 & 1424.64 & 47.26 & After raining ( $(16 / 10 / 2015)$. \\
\hline 15 & 0.651 & 215.39 & 1485.67 & 49.65 & No Rains ( $27 / 10 / 2015)$ \\
\hline 16 & 3.663 & 179.24 & 1409.28 & 46.78 & Rains $(17 / 11 / 2015)$ \\
\hline 17 & 2.587 & 183.91 & 1423.89 & 47.18 & After raining ( $17 / 11 / 2015)$. \\
\hline 18 & 0.832 & 214.14 & 1476.51 & 49.57 & No Rains ( $28 / 11 / 2015$ ). \\
\hline 19 & 3.843 & 178.76 & 1408.42 & 46.73 & Rains $(18 / 12 / 2015)$ \\
\hline 20 & 2.495 & 183.25 & 1423.25 & 47.12 & After raining $(18 / 12 / 2015)$. \\
\hline
\end{tabular}

\subsection{Coefficient correlation}

coefficient correlation can be calculated using equation 16 as follows:

$$
\begin{aligned}
& r_{x y}=\frac{-6541.2689}{\sqrt{(477.471356)(94851.4975)}} \\
& r_{x y}=\frac{-6533.522}{\sqrt{45288873.12995561}}=-0,97
\end{aligned}
$$

From the calculation, the negative correlation coefficient of -0.97 indicates a negative relationship between cosentration sedimentation $\mathrm{C}$ (g / lt) with the generator voltage (volts), so when the cosentration sedimentation $\mathrm{C}$ increases, the generator voltage will drop.

\subsection{Compatibility of Model}

To test the hypothesis in correlations is to find the value of the correlation coefficient $\mathrm{t}$ statistic is then compared with t-table, so do the calculation in advance of $t$-count value correlation with the equation 15 so magnified by the following calculation: $\mathrm{t}_{\mathrm{o}}=\left|\frac{\mathrm{r} \sqrt{\mathrm{n}-2}}{\sqrt{1-\mathrm{r}^{2}}}\right| \quad \mathrm{t}_{\mathrm{o}}=\left|\frac{-4.115}{\sqrt{1-0.9409}}\right|=16,92$

T-table value obtained from a table $t$ obtained the value t-table $(0: 05,18)$ is equal to 2,101 , the value when compared with t-test of 16.92 , then $t$ count $>t$ table at $\alpha=5 \%$, so dinyataka that there a significant relationship between cosenrtation sedimentation $\mathrm{c}(\mathrm{g} / \mathrm{lt})$ with the generator voltage (volts). In the same way, the obtained three relational equation Y2 (round) and Y3 (frequency).and the Characteristics of the equation relationship as shown in the Fig. 4. 

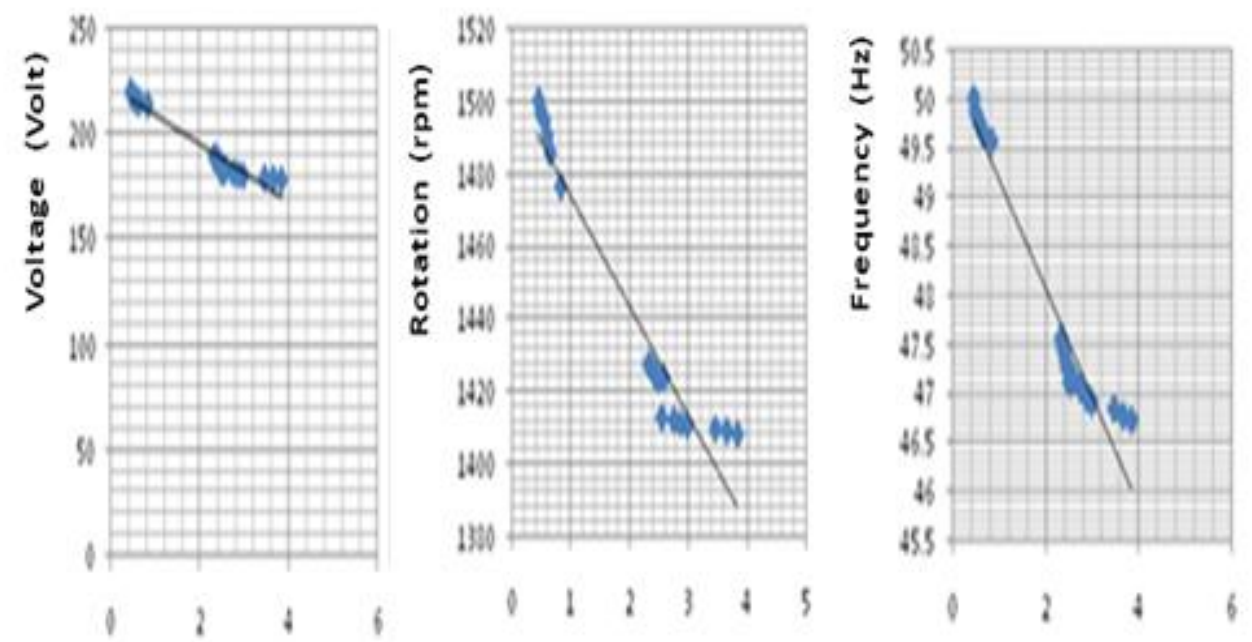

\section{Cosentrationsedimentation $\mathrm{C}(\mathrm{g} / \mathrm{It})$}

Fig.4: Characteristics of sedimentation Concentration againts voltage,rotation and frequency generator that circumstances not rains, rains and after rains

2. Observations the MHP in the rain.

During the rainy season from field observations seen that happen turbidity caused by the lifting of soil sediments greatly affect the quality of the electrical power produced. Linear regression model the effect of concentration of sedimenn row against voltage generator, turbine-generator and frequency generator when it rains. From table 2 are:

$\mathrm{Y}_{1 \mathrm{~h}}=-0.07+181.56 \mathrm{X} ; \quad \mathrm{Y}_{2 \mathrm{~h}}=-1.06+1401.45$

$\mathrm{X} ; \quad \mathrm{Y}_{3 \mathrm{~h}}=-0.04+46.72 \mathrm{X}$

The characteristic shape image sedimentation concentration and voltage generator on table II

Tabel II. Data of sedimentation Concentration againts voltage,

Rotation and frequency generator that circumstances rains

\begin{tabular}{|c|c|c|c|c|}
\hline $\begin{array}{c}\text { No } \\
\text { sa mpel }\end{array}$ & $\begin{array}{c}\text { Concentration } \\
\text { sedimentation } \\
\text { c(g/l) } \\
\mathbf{X}\end{array}$ & $\begin{array}{l}\text { Volage } \\
\text { Gen V } \\
\text { (Volt) } \\
Y_{1}\end{array}$ & $\begin{array}{c}\text { Rotation } \\
\text { tur/gen } \\
\text { n(r pm) } \\
\mathbf{Y}_{2}\end{array}$ & $\begin{array}{c}\text { Frequency } \\
\text { (I: ) } \mathbf{Y}_{3}\end{array}$ \\
\hline 1 & 3.864 & 178.41 & 1354.2 & 45.14 \\
\hline 2 & 2.987 & 181.78 & 1402.8 & 46.76 \\
\hline 3 & 3.843 & 179.53 & 1357.8 & 45.26 \\
\hline 4 & 3.267 & 180.64 & 1398.3 & 46.61 \\
\hline 5 & 2.965 & 180.95 & 1404.9 & 46.83 \\
\hline 6 & 3.864 & 178.84 & 1359.6 & 45.32 \\
\hline 7 & 3.663 & 181.24 & 1371.9 & 45.73 \\
\hline 8 & 3.683 & 178.97 & 1365.3 & 45.51 \\
\hline 9 & 2.875 & 183.44 & 1415.1 & 47.17 \\
\hline 10 & 2.792 & 182.64 & 1416.3 & 47.21 \\
\hline 11 & 2.889 & 181.34 & 1409.4 & 46.98 \\
\hline 12 & 2.776 & 183.87 & 1422.9 & 47.43 \\
\hline 13 & 3.643 & 179.53 & 1376.7 & 45.89 \\
\hline 14 & 2.756 & 184.14 & 1425.3 & 47.51 \\
\hline 15 & 3.487 & 181.24 & 1388.4 & 46.28 \\
\hline 16 & 2.586 & 182.54 & 1430.4 & 47.68 \\
\hline 17 & 3.467 & 179.86 & 1391.1 & 46.37 \\
\hline 18 & 2.562 & 183.72 & 1435.5 & 47.85 \\
\hline 19 & 3.447 & 181.24 & 1397.4 & 46.58 \\
\hline 20 & 2.551 & 182.94 & 1437.6 & 47.92 \\
\hline
\end{tabular}

Retrieved voltage deviation $\mathrm{Vd}=17.6 \%, \mathrm{Fd}$ frequency deviation $=6.8 \%$ and the deviation rotation $\mathrm{Nd}=6.8 \%$ in sediment concentration $\mathrm{C}=$ 1.00 to $2.50 \mathrm{~g} / 1$ (mediu m), $2.50-5.00 \mathrm{~g} / 1$ and the linear regression equation obtained shown in the Fig. 5. 

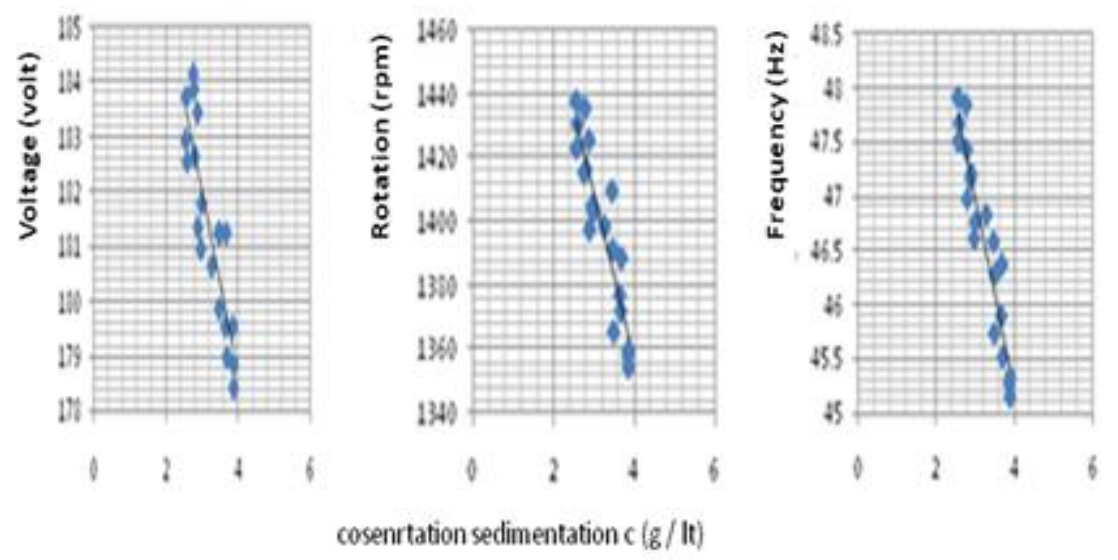

Fig. 5. Characteristics of sedimentation Concentration againts voltage, rotation and frequency generator that circumstances rain

rotation $\mathrm{Nd}=6.8 \%$ in sediment concentration $\mathrm{C}=$ 1.00 to $2.50 \mathrm{~g} / 1$ (mediu m), $2.50-5.00 \mathrm{~g} / 1 \mathrm{ugly}$. MHP running condition is not normal on the boundary voltage parameters, rotation and frequency that is not permitted where the voltage of $>5 \%$ and the frequency and rotation $>2 \%$.

\section{CONCLUSION}

1. The existence of a negative correlation between kosenrtasi sedimentation $\mathrm{C}$ ( $\mathrm{g} / \mathrm{lt}$ ) with the generator voltage (volts), the turbinegenerator rotation $\mathrm{n}(\mathrm{rpm})$, and the frequency $\mathrm{f}$ $(\mathrm{Hz})$ of the MHP meaning if kosenrtasi sedimentation $\mathrm{C}$ increases, the voltage generator, rotation turbine-generator $\mathrm{n}(\mathrm{rpm})$, and the frequency $\mathrm{f}(\mathrm{Hz})$ of the MHP is going down.

2. At the time of the MHP rainy conditions without setling basin modeling obtained voltage deviation $\mathrm{Vd}=17.6 \%, \mathrm{Fd}$ frequency deviation $=6.8 \%$ and the deviation rotation $\mathrm{Nd}$ $=6.8 \%$ at a concentration of between 2.551 sedimentation $\mathrm{C}(\mathrm{g} / \mathrm{l})$ and $3864(\mathrm{~g} / \mathrm{l})$ where the value of $\mathrm{C}$ category (C> 2.5 (g/1) Ugly) MHP operating conditions are not normal,

3. Provide recommendations concentration sedimentation can take affect turbine type Plopeler Open Flume conducted in this study, therefore, need their setling modeling to reduce the influence of the sedimentation basin

\section{REFERENCES}

[1]. Abdul Azis Hoesein, Lily M (2011) Design Of Micro Hydro Electrical Power At Brang Rea River In West Sumbawa Of Indonesia, ISSN 2088-3218 Vol.1.Number 2 : 177 183 ,August , (C) T2011 Depar tment of Envi ronmental Engineering

[2]. A.H. Sajedi Poor, N M. Mashal, Hedayat (2010) Analytical Study Of Sedimentation Formation In Lined Canals, Using The Sharc Software- A Case Study Of The Western Intake Structure Indez Diversion Weir In Dezful, Iran, Juor.of Engineering.

[3]. Amir Abbas, Kamanbedast (2010) Investigation Of Sediment Depth-Volume

And Seepage (With Using Water Stops Materials) In Canals Of Irrigation Network World Applied Sciences Journal (C) IDOSI Publications,

[4]. Arifin Matoka, Nadjamuddin H. , Salama M and M. Arsyad T. Modeling Precipitating Tub (Settling Basin) For Reduction Sedimentation Effect in Irrigation Channel at Micro Hydro Power (Case Study At Gorontalo Province Irrigation Channel), International journal Of Enginerring Reasearch and Aplications ISSN 2248-9622, Vol 6, Issue 5 (Part 6) May 2016 pp.01-08

[5]. Arifin Matoka, Nadjamuddin H. , Salama M and M. Arsyad T. Analysis Effect of Sedimentation on the MHP in Irrigation canals and Modeling Settling Basin to Reduce it (Case Study Irrigation Gorontalo 
Province) Proceding of the $1^{\text {st }}$ International Conference on Technology,Innovation, and Society (ICTIS) 2016

[6]. Bilal Abdullah Nasir (2013) Design Of High Efficiency Pelton Turbine For Microhydropower PlantInternational Journal Of Elec. Eng.\& Tech (Ijeet)

[7]. D. L. Carter, C. E. Brockway (1993) Controlling Erosion And Sediment Loss From Furrow-Irrigated Cropland Jour.of Irrigation and Drainage Eng. Vol. 119, (C)ASCE.

[8]. G H. H. Karimi , H. Moazed, Hamidieh (2012) Settling And Non Settling Velocities In Irrigation Canals, And Ghods Irrigation Network, African Journal of Agricultural Research Vol. 7(22).

[9]. Hongling Shi, at all (2008) 1-D Sediment Mathematical Model Forirrigation Canals Of The Lower Yellow River World Environmental And Water Resources Journal Congress 2008 Ahupua'a 2008 ASCE

[10]. Hrishikesh. U. at all (2013) Design and Development of Low Cost Micro Hydro Power Station for Agro based Application International Journal of Scientific \& Engineering Research, Volume 4, Issue 4, April- 889 ISSN 2229-5518 IJSER (C)

[11]. Irhan Febijanto (2008) Pemanfaatan Potensi Tenaga Air Di Saluran Irigasi Banjarcahyana, Kabupaten Banjarnegara, Propinsi Jawa Tengah Sebagai Usaha Pengurangan Emisi Gas Rumah Kaca Jurnal. Tek. Ling Vol. 9 No. 3 Hal. 277-286 Jakarta, September ISSN 1441-318X

[12]. Issam Salhi1, Said Doubabi (2009) Fuzzy controller for frequency regulation and water energy save on microhydro electrical power plants International Renewable Energy Congress November 5-7, Sousse Tunisia

[13]. K.G. Ranga Raju , U.C. Kothyari (2004) Sediment Management In Hydroelectric Projects Proceedings of the Ninth International Symposium on River Sedimentation October 18 - 21, 2004, Yichang, China M.A. Wazed,

[14]. Shamsuddin,Ahmed (2008) Micro Hydro Energy Resources in Bangladesh: A Review Australian Journal of Basic and Applied Sciences ISSN1991-8178 @ 2008, INSInet Publication

[15]. Nadjamuddin H (2012) Perancangan Pembangkitan Tenaga Listrik, Membumi Publishing, Makassar ISBN : 978-60219613-0-8

[16]. O Paish (2012) Small Hydro Power: Technology And Current Status Renewable and Sustainable Energy Reviews www.els evier.co m/locate/rser 